\title{
Correction to: A Novel Protein Sequence Alignment-Based Patch Similarity Estimation for Two-Level Data Aggregation in WMSNs
}

\author{
M. Nava Barathy ${ }^{1}$ D. D. Dejey ${ }^{1}$
}

Published online: 11 March 2021

(C) Springer Science+Business Media, LLC, part of Springer Nature 2021

\section{Correction to: Wireless Personal Communications https://doi.org/10.1007/s11277-021-08099-7}

The author names were incorrectly captured in the initial online publication. The original article has been corrected.

Publisher's Note Springer Nature remains neutral with regard to jurisdictional claims in published maps and institutional affiliations.

The original article can be found online at https://doi.org/10.1007/s11277-021-08099-7.

M. Nava Barathy

navabarathy.m@auttvl.ac.in

1 Department of Computer Science and Engineering, Anna University Regional Campus Tirunelveli, Tirunelveli 627007, India 